\title{
Calf Rearing Management Practices Followed in Rural Areas of Western Haryana, India
}

\author{
Vikas Godara ${ }^{1}$, Narender Singh ${ }^{1 *}$, Sushil Kumar ${ }^{2}$ and Robin ${ }^{3}$ \\ ${ }^{1}$ Department of Livestock Production Management, ${ }^{2}$ Department of Animal Nutrition, \\ ${ }^{3}$ Department of Veterinary Pharmacology and Toxicology, LUVAS, Hisar (Haryana), India \\ *Corresponding author
}

\section{A B S T R A C T}

\section{Keywords}

Western Haryana, Rural, Buffalo calf, Newborn, Management.

Article Info

Accepted:

21 October 2017

Available Online:

10 December 2017
The present investigation was conducted in two districts (Bhiwani, Sirsa) of Western Haryana. Further two tehsil were selected from each district and two villages from each tehsil were selected randomly. Twenty five buffalo rearers from each of village were selected thus making a sample of 200 buffalo rearers. Results of this study revealed that, most of respondents attended buffaloes at time of calving and trimmed hooves of the calf after birth. Majority 92.50 per cent of the respondents did not cut naval cord of calf. About 35.50 per cent owners disposed off placenta by throw off in open area. It was found that 53.00 per cent of the owners allowed suckling calf up to 6 month. More than half (55.00 and 23.50 per cent) of buffalo keepers did not perform deworming and tickllice eradications measures in calves. So in addition to the traditional knowledge scientific knowledge for this aspect is also important. For this we can organize trainings to farmers by Krishi Vigyan Kendra and Krishi Gyan Kendra on all aspect of buffalo calf management. So that as a result we can get superior animals for future.

\section{Introduction}

Buffalo rearing in Haryana is an important sector for providing a stable source of income to rural farmers. As far as western Haryana is concerned Due to lack of detailed information on existing breeding, feeding, housing and other managerial practices adopted for different categories of livestock, it has not been possible to give full attention to these important aspects of buffalo production. The reason for this is mainly due to poor production potential of dairy animals, inadequate management practices including calf rearing practices (Ahirwar et al., 2011). Considering these facts there is a vast scope for increased productivity through improved management practices including calf rearing practices in order to get maximum profits (Singh et al., 2012). Proper management and constant attention is required for calves, as they form the future dairy herd and are the basis for maintaining the production level of any dairy farm. Good calf rearing practices provide better scope for better future dairy animals. So an effort is done to gain knowledge of existing calf management practices prevalent in western Haryana. Further findings of this study will provide a feasible and relevant package of buffalo calf management practices adopted by the buffalo keepers of western Haryana. 


\section{Materials and Methods}

The present study conducted in Bhiwani and Sirsa districts of western Haryana. Two tehsils from each selected district were identified, which were Loharu, Dadri, Sirsa and Rania (Table 1). Further two villages were selected from each tehsil. The 25 respondents were selected randomly from each village. Thus, the entire sample consists of 200 respondents from selected eight villages. While selecting respondents due care was taken to ensure that they were evenly distributed in the village and truly represented animal management practices prevailing in the area. The selected farmers were interviewed and the information was collected with help of predesigned questionnaire. For collecting information pertaining calf rearing management practices adopted by farmers, questions were included were attending calving and taking care of the calves after it, colostrums feeding to the new born calf, quantity of colostrums, age of weaning of calves, feeding of calf starter and age at which fodder was given to the calves, deworming of calves and lice/ticks eradication etc.

\section{Statistical analysis of data}

To analysis the collected information, basic statistical tools and methods were used. The statistical tools were used for interpretation of data are 1) Frequency Distribution for the total numbers of respondents in the survey and 2) percentage for simple comparisons were made on the basis of percentage.

\section{Results and Discussion}

The results of the study regarding calf management practices adopted by farmers for their dairy animals are presented in Table 2. It was observed that only 69.00 the respondents attended the buffaloes as well as calf at the time of calving. More than half 67.00 per cent of the respondents were following the practices of cleaning the calf immediately after birth as well as trim hooves and allowed the dam to lick her calf immediately. Present findings are similar to the findings of Meena et al., (2008). However, Malik and Nagpal (1999), Khadda et al., (2010), Kumar and Mishra (2011a) reported that all of the respondent attended calving and took care of calves after parturition. It was observed that 92.50 per cent buffalo keepers did not follow the practice to cut and disinfect the naval cord. Very few buffalo keepers cut the naval cord with new blade or knife and tied it with thread. It is due to lack of knowledge and awareness about the importance of these practices.

Hence, more efforts are required to motivate farmers to follow this practice. These findings are similar with the results recorded by Saharan et al., (2015) Khadda et al., (2010) and Maousami et al., (2013). However, these are contrary to the results of Malik and Nagpal (1999), Pawar et al., (2006), Gill and Saini (2008), Rathore and Kachwaha (2009) and Rathore et al., (2010) who observed that 37.00 to $85.56 \%$ of the respondents followed these practices.

It was observed that $26.50,38.00$ and 35.50 per cent of the respondents provided colostrum within two hours of birth, 2 to 4 hours after birth and after fall of placenta, respectively. These finding are in close line to finding of Deshmukh et al., (2009), Rathore and Kachawaha (2009) and Rathore et al., (2010). Quantity of colostrum feeding was $a d$ lib, and half quarter by new born calfs were followed by 47.00 , and 51.00 per cent of the respondents, respectively. Present findings are similar to the result of Kumar and Mishra (2011a). 
Table.1 Selection plan of respondents

\begin{tabular}{|l|l|l|l|}
\hline Districts & Tehsil & Village & No of respondents \\
\hline \multirow{3}{*}{ Bhiwani } & \multirow{2}{*}{ Loharu } & Patwan & 25 \\
\cline { 3 - 4 } & & Chahar Kalan & 25 \\
\cline { 2 - 4 } & \multirow{2}{*}{ Dadri } & Chappar & 25 \\
\cline { 3 - 4 } & & Adampur Dadhi & 25 \\
\hline \multirow{3}{*}{ Sirsa } & Rania & Mammer Khera & 25 \\
\cline { 3 - 4 } & & Kherawala & 25 \\
\cline { 2 - 4 } & \multirow{2}{*}{ Sirsa } & Bakriyawali & 25 \\
\cline { 3 - 4 } & & Jodhkan & 25 \\
\hline
\end{tabular}

Table.2 Existing calf rearing management practices in Western Haryana

\begin{tabular}{|c|c|c|}
\hline S.No EXISTING Practices & Frequency & Percentage \\
\hline \multicolumn{3}{|c|}{ 1.Attended the buffalo at the time of calving } \\
\hline a.Yes & 138 & 69.00 \\
\hline b.No & 62 & 31 \\
\hline \multicolumn{3}{|c|}{ 2.Feeding of colostrum of the calf } \\
\hline a.Within two hours of birth & 53 & 26.50 \\
\hline b.Two to four of birth & 76 & 38.00 \\
\hline c.After Dropping of Placenta & 71 & 35.50 \\
\hline \multicolumn{3}{|c|}{ 3.Cut and disinfect the naval cord of calf } \\
\hline a.Yes & 15 & 07.50 \\
\hline b.No & 185 & 92.50 \\
\hline \multicolumn{3}{|c|}{ 4. Clean the calf immediately after birth and trim the hooves } \\
\hline a.Yes & 134 & 67.00 \\
\hline b.No & 66 & 33.00 \\
\hline \multicolumn{3}{|c|}{ 5.Quantity of colostrum feeding } \\
\hline a.Adilib sucking & 94 & 47.00 \\
\hline b.One quarter & 04 & 02.00 \\
\hline c.Some milk in all Quarters & 102 & 51.00 \\
\hline d.As per body weight & 00 & 00.00 \\
\hline \multicolumn{3}{|c|}{ 6.Measures do you apply when the placenta is not expelled in time } \\
\hline a.Veterinary staff help & 71 & 35.50 \\
\hline b.Quack help & 74 & 37.00 \\
\hline c.Ethno Veterinary medicine & 55 & 27.50 \\
\hline \multicolumn{3}{|l|}{ 7.Disposal of the placenta } \\
\hline a.Throw off & 71 & 35.50 \\
\hline b.Deep Buried & 129 & 64.50 \\
\hline \multicolumn{3}{|l|}{ 8.Duration of suckling of calf } \\
\hline a.Weaning (just after birth) & 00 & 00 \\
\hline b.Up to six months & 106 & 53.00 \\
\hline c.Less than four month & 90 & 45.00 \\
\hline d.More than six month & 04 & 2.00 \\
\hline \multicolumn{3}{|l|}{ 9.Deworming of clave } \\
\hline a.Yes & 110 & 55.00 \\
\hline b.No & 90 & 45.00 \\
\hline \multicolumn{3}{|c|}{ 10.Lice/ticks eradication measures followed } \\
\hline a.Yes & 153 & 76.50 \\
\hline b.No & 47 & 23.50 \\
\hline
\end{tabular}


Buffalo keepers disposed of placenta by deep buried 64.50 per cent and throw in out skirt common land about 35.50 per cent. The majority 53.00 per cent of the respondents allowed suckling to their claves up to six months of age, whereas, 45.00 and 2.00 per cent of the respondents allowed suckling less than four months and above 6 months of age, respectively.

Majority of the respondents (76.50 per cent) took control measures of lice and ticks eradication, but the practice of calf deworming was followed by only 55 per cent buffalo keepers. The result of calf deworming practice observed in this study was in line to the finding of Malik et al., (2005), Gupta et al., (2008) and Rathore et al., (2010). These results indicate that deworming practice is commonly followed by most of respondents.

By studying the results of this investigation it can be concluded that calf management is very necessary for better future of a dairy herd or farm. It is necessary that farmers should have proper knowledge about caring of a calf just after the birth and later on. So in addition to the traditional knowledge scientific knowledge for this aspect is also important. For this we can organize trainings to farmers by Krishi Vigyan Kendra and Krishi Gyan Kendra on all aspect of buffalo calf management. So that as a result we can get superior animals for future.

\section{References}

Ahirwar R R, Nanavati S and Nayak N K. (2011). Feeding and breeding management of buffaloes under rural and urban areas of Indore district of M.P. Indian J. Field Vet. Vol. 6: 29-30.

Deshmukh, M. S., Pathan, I. H., Shaikh, S. H. and Siddiqui, M. F. (2009).A study on the buffalo farmer perception about colostrum feeding in Hingolidistrict.
National symposium on 'organic livestock farming- global issues, trends and challenges' held 26th-28th February, 2009 at Kolkata. ISAPM. Pp. 95.

Gill, T. K. and Saini, S. K. (2008). A study of awareness of recommended dairy practices among farmers. Internat. $J$. Agric. Sci., 4(1): 296-300.

Gupta, D. C., Suresh, A. and Mann, J. S. (2008).Management practices and productivity status of cattle and buffaloes in Rajasthan. Indian J. Anim. Sci.78(7): 769-774.

Khadda, B. S., Lata, K., Jadav, J. K., Kalash, P. and Kumar, R. (2010). Study on calves management practices in tribal and non-tribal areas of Panchmahals district of Gujarat. Journal of Progressive Agriculture, 1(1): 84-86.

Kumar, S. and Mishra, B. K. (2011a). Existing calf rearing and milking management practices followed by dairy farmers in Uttarakhand. Journal of Hill Agriculture, 2(1): 79-84.

Kumar, S. and Mishra, B. K. (2011a). Existing calf rearing and milking management practices followed by dairy farmers in Uttarakhand. Journal of Hill Agriculture, 2(1): 79-84.

Malik, B. S., Meena, B. S. and Rao, S. V. N. (2005).Study of existing dairy farming practices in Uttar Pradesh. J. Dairying, Foods \& Home Sci., 24(2): 91-95.

Malik, D.S. and Nagpaul, P.K. (1999). Studies on milking and calf rearing management practices of Murrah buffalo in its home-tract of Haryana. Indian J. Anim. Prod.Mgmt. 15(2): 5254.

Maousami, Singh, B. P., Kumar, R., Kumar, V. and Dohare, A. (2013.Analysis of buffalo calf management practices followed by buffalo owners. $J$ AnimSciAdv, 3(3): 129-133.

Meena, H. R., Ram, H., Sahoo, A. and 
Rasool, T. J. (2008). Livestock husbandry scenario at high altitude kumaon Himalaya, Indian Journal of Animal Sciences, 78(8): 882-886

Pawar, B. K., Nalawade, T. H. and Jagtap, D. Z. (2006).Adoption of bovine heeding practices and constraints faced by tribal farmers of Pune district. J. Maha. agric. univ., 31(3): 329-330.

Rathore, R. S. and Kachwaha, R. N. (2009). Studies on existing management practices followed by the buffalo owners in Jhunjhunu district of Rajasthan. Indian J. Anim. Prod. Mgmt., 25(1-2): 8-11.

Rathore, R. S., Singh, R. and Tiwari, A. (2010b).Studies on various existing managemental practices followed by the crossbred cattle owners. Indian J. Anim. Prod. Mgmt., 26(1-2): 85-88.

Rathore, R. S., Singh, R., Kachwaha, R. N. and Kumar, R. (2010a). Existing management practices followed by the cattle keepers in Churu district of Rajasthan. Indian Journal of Animal Sciences, 80(8): 798-805.

Rathore, R.S., Singh, R., Kachawaha, R.N. and Kumar, R. (2010).Existing management practices followed by the cattle keepers in Churu district of Rajasthan. Indian J. Anim. Sci. 80 (8): 798-805.

Saharan, J.S., Choudhary, V.K., Goswami, S.C., Bais, B., Jhirwal, A.K., Gadhwal, R.S., Mahla, V., Choudhary, S. and Kumar, S. (2015). Study on calf rearing management practices adopted by Tharparkar cattle breed keepers of Western Rajasthan. Vet. Practioner, 16(2): 327-328.

Singh S K, Agarwal S B, Chandel, B S. (2012). Resource use efficiency in buffalo milk production in Varanasi district of Uttar Pradesh India. J. Dairying, Foods \& H. S. 31: 259-263, 2012.

\section{How to cite this article:}

Vikas Godara, Narender Singh, Sushil Kumar and Robin. 2017. Calf Rearing Management Practices Followed in Rural Areas of Western Haryana, India. Int.J.Curr.Microbiol.App.Sci. 6(12): 2996-3000. doi: https://doi.org/10.20546/ijcmas.2017.612.350 